\title{
THE RESPONSE OF NONFARM INCOME TO CONDITIONS IN AGRICULTURAL MARKETS: AN APPLICATION OF MULTIVARIATE ANALYSIS OF VARIANCE (MANOVA)
}

\author{
M.T. Makhura, J.F. Kirsten \& M.M. Mathye ${ }^{1}$
}

The Multivarinte Analysis of Variance (MANOVA) is applied on datn of 157 households from the Northern Province to test the significante of the response of nonfarm enrnings to the access of agricultural markets. The market access (and their interactions) involved cash market, exchange for finished product, and value adding at household level, while the nonfarm income responses emanted from local sources, commuting, and migration. The results reflect that nonfarm incomes are not crucial when farmers have access to all market options, since they can generate boll income and cusure food security from farming. However, when markets are not fully accessible, nonfarm incomes (from migrants and local sources) tend to play a supplementary role. By the nature of its entrance requirements, income from commuting is not a result of conditions in the markets. Nonetheless, there is cnongh evidence of the existence of linkages between conditions in agricultural markets and engagement in nonfarm income. To enhance such linknges would require provision of infrastructure, communications, information and transport nethorks.

\section{INTRODUCTION}

Although a majority of rural households in South Africa depend on agriculture, farm production is normally not sufficient to sustain the basic needs (MALA, 1998). Some 30 to $50 \%$ of the population has insufficient food, is exposed to an imbalanced diet, as a result of low incomes (APU, 1997). The dual objectives in farming are to earn income and ensure food security' (World Bank, 1995). As such, households use different marketing channels to achieve such objectives (NAMC, 1999). When these markets are not reliable or nonexistence (Jayne et al., 1994), farmers respond by engaging in nonfarm activities to supplement the deficiency of agricultural markets (May, 1996, 1997 and Baber, 1996). The paper aims to determine the behaviour of farmers in adopting nonfarm activities when faced with different conditions of market access. In most rural areas of South Africa, farming income contributes far less than nonfarm income in the total income (Delgado, 1997).

1 Department of Agricultural Economics, Extension and Rutral Development; University of Pretorin. 
Literature on farm-nonfarm linkages can be subdivided into two major areas of orientation. The first body of literature tend to show the role of nonfarm activities in stabilising incomes of rural households (Baber, 1996 and May 1996) and rural economies (van Dijk, 1986; Kirsten, 1995 and Liedholm et al, 1994). Nonfarm activities are an important source of cash income that can be used to finance farming activities and smoothing incomes inter-annually (Reardon et al, 1994; Islam, 1997). Most of these studies attempt to demonstrate the high share of nonfarm income as compared to farm income share with the implication of development as agriculture's role declines (Timmer, 1990). Linked to this is allocation of labour to farm and nonfarm activities (Kawanogoe, 1994; and Abdulae et ill., 1999).

The second body of literature explores growth linkages between farm and nonfarm sector (Delgado et al, 1994; 1998 and Ngqangweni, Kirsten \& Delgado, 1999). These studies attempt to motivate how increased rural incomes are spent on consumption items with implications for rural growth. Other discussions pertain to linkages of agriculture to the rest of the macroeconomy (van Rooyen, 1997).

Relatively fewer studies tend to explore factors driving households to diversify outside of agriculture (Reardon et al, 1992 and Reardon et al., 1994). This paper aims to determine how nonfarm activities respond to access to agricultural markets. The study is supplementary to the work of Olfert (1992) which evaluated nonfarm employment as a response to underemployment in agriculture. When farmers are faced with market uncertainties, they usually choose other avenue, such as diversification strategies to reduce risk exposure (Zaibet \& Dunn, 1998). A multivariate analysis of variance (MANOVA) model is implemented for that purpose.

\section{DEVELOPMENT AND SPECIFICATION OF MANOVA MODEL}

The objective of this paper is to test the significance of households' nonfarm income responses; local sources $\left(Y_{1}\right)$, commuting $\left(Y_{2}\right)$, and migration $\left(Y_{3}\right)$ to indicators of agricultural market access; direct cash market $\left(X_{1}\right)$, value adding exchange $\left(X_{2}\right)$, and value adding at household level $\left(X_{3}\right)$. The multivariate analysis of variance (MANOVA) is used for two reasons. There are three categorical indicator or explanatory variables $\left(X^{\prime} s\right)$ and three response variables ( $\left.Y^{\prime} s\right)$. The linear regression and analysis of variance cannot be applied since the effects and responses should be determined simultaneously for both sets of variables. 
The benefit of MANOVA is its ability to simultaneously explore the effect of several categorical independent variables on the variance of a group of dependent variables (Mamabolo, 1998). In simple terms MANOVA can be stated in the following form;

$$
Y_{1}+Y_{2}+Y_{3}+\ldots \ldots Y_{n}=X_{1}+X_{2}+X_{3}+\ldots \ldots . X_{n}
$$

where $Y$ is a metric response variate and $X$ is a nonmetric factor (Hair et al, 1995).

The Multivariate two-way fixed-effect model can be developed based on Mamabolo (1998) and Johnson \& Wichern (1992). Suppose there are $g$ levels of factor $1, b$ levels of factor 2 , and $n$ independent observations can be observed at each of the $g b$ combinations levels. Denoting the $r$ th observation at level $\imath$ of factor 1 and level $k$ of factor 2 by $X_{t k r}$, the multivariate two-way model is

$$
\begin{aligned}
X_{t k r} & =\mu_{t k r}+\tau_{1}+\beta_{k}+\gamma_{l k}+e_{t k r} \\
l & =1,2, \ldots . ., g ; \quad k=1,2, \ldots \ldots, b ; \text { and } \quad r=1,2, \ldots \ldots, n
\end{aligned}
$$

where

$$
\sum \tau_{t}=\sum \beta_{k}=\sum \gamma_{t k}=\sum \gamma_{j k}=0
$$

with summations running as defined above.

The dimensions of all vectors are $p \times 1$ and $\mathbf{e}_{i k r}$ is assumed to be an $N_{p}(0, \Sigma)$ random vector. Thus the responses consist of $p$ measurements replicated $n$ times at each of the possible combinations of levels of factors 1 and 2 .

The observation vectors can be decomposed as

$$
x_{t k r}=\bar{X}+\left(\bar{X}_{t \cdot} \cdot \bar{X}\right)+\left(\bar{X}_{t k}-\bar{X}\right)+\left(\bar{X}_{t k r}-\bar{X}_{t}-\bar{X}_{t k}+\bar{X}\right)+\left(\bar{X}_{t k r}-\bar{X}_{t k}\right)
$$

where $\bar{X}$ is the overall average of the observations vectors.

Squaring and summing the deviations gives a break-up of the sum of squares and cross-products and degrees of freedom as

$$
\begin{aligned}
& \mathrm{SSP}_{\text {cor }}=\mathrm{SSP}_{\mathrm{fac} 1}+\mathrm{SSP}_{\mathrm{far} 2}+\mathrm{SSP}_{\mathrm{int}}+\mathrm{SSP}_{\mathrm{res}} \mid \\
& g b n-1=(g-1)+(b-1)+(g-1)(b-1)+g b(n-1)
\end{aligned}
$$


The F-ratio of the mean squares of effect terms to error can be used to test for the effects of factor 1, factor 2, and factor 1-factor 2 interactions using Wilks lamda. Other tests include Pillai-Barlett, the Hotteling-lawley trace and Roy greatest characteristics root (Mathobo, 1999).

MANOVA model is not frequently applied in social sciences. Some cases where it was applied involved determination of farmers' beliefs and adoption of integrated Pest Management (Musser et al., 1986), and measurement of attitude as a way of differentiating entrepreneurs (Boshoff \& Scholtz, 1995). As such, this paper aims to add to the literature applying this model.

A statistical model was developed to determine the response of nonfarm income sources to agricultural market access. The vector of dependent variables represents nonfarm income per adult equivalent (AE) indicated by income from local sources (LOCINC), commuting (COMTINC), and migration (MIGRINC). LOCINC reflects business activities, services, pensions, agribusiness, and farming activities. COMIINC reflects salaries from public service, and MIGRINC reflects income from wages by migrants. The vector of independent variables represents access to agricultural markets. This include three factors; MKTSELL indicating whether household marketed its produce for cash or not, MKTEXC indicating whether the household exchanged its produce for value added products from other institutions or not, and MKTSELF indicating whether the household added value to its farm produce by itself or not.

The MANOVA model was specified as;

LOCINC + COMTINC + MIGRINC = MKTSELL + MKTEXC + MKTSELF + MKTSELL*MKTEXC +MKTSELL*MKTSELF + MKTEXC*MKTSELF + MKTSELL*MKTEXC*MKTSELF

\section{EMPIRICAL RESULTS}

The statistical model in this study was tested using 1997 data from a sample of 157 farming households in the Northern Province. The data was gathered through interview using structured questionnaire. The respondents were asked to indicate sources and amounts of income. They were further asked to indicate value of farm produce from direct sales, products exchanged, and kept for own consumption. The multivariate test for homogeneity of dispersion matrix show significance with Box $M=291,77$, and F WITH (42, 5701) $\mathrm{DF}=6,21$ and chi-square (with $42 \mathrm{DF}$ ) of 262.87 , both significant at one 
percent. Further, the correlation of the response variables within categories was reasonable.

Table 1 displays the results of the multivariate test of significance of various parameters of market access combination. The values of three tests of significance are presented, namely Pillai's Trace, Hotteling-Lawley Trace and Wilks lamda. When there are two groups all the three statistics give the same value of the F statistics. In addition, it indicates univariate F-tests (with 1,148 DF). The hypothesised sum of squares and error sum of squares are not presented, but the F-values and their significance.

Table 1: Multivariate test of nonfarm response to markets

\begin{tabular}{|c|c|c|c|c|c|c|}
\hline \multirow[t]{2}{*}{ Effect } & \multicolumn{3}{|c|}{$\begin{array}{c}\text { Multivariate test of } \\
\text { significant }\end{array}$} & \multicolumn{3}{|c|}{ Univariate f-test $(1,148) \mathrm{df}$} \\
\hline & Pillais & Hottellings & Wilks & LOCINC & COMTINC & MIGRINC \\
\hline $\begin{array}{l}\text { MKTSELL`MKTEXC } \\
\text { MKTSELF }\end{array}$ & .0134 & .0136 & .9866 & 1.442 & .142 & .5967 \\
\hline MKTECX*MKTSELF & .0288 & .0297 & .9712 & $3.661^{\star}$ & .344 & .0032 \\
\hline MKTSELL*MKTSELF & $.072^{\star \star}$ & $.077^{\star \star}$ & $.929^{\star \star \star}$ & $5.797^{\star \star}$ & .251 & $5.997^{* \star}$ \\
\hline MKTSELL*MKTEXC & .0372 & .0386 & .9628 & 2.389 & .614 & $3.245^{\star}$ \\
\hline MKTSELF & .0183 & .0186 & .982 & 1.172 & .014 & 1.432 \\
\hline MKTEXC & .0218 & .0223 & .978 & .205 & 2.156 & .657 \\
\hline MKTSELL & .0321 & .0332 & .9679 & $4.626^{\star \star}$ & .008 & .192 \\
\hline
\end{tabular}

* significant at $10 \%,{ }^{* *}$ significant at $5 \%$, ${ }^{* \star *}$ significant at $1 \%$

The three-way interactions among MKTSELL, MKTEXC and MKTSELF are not significant. All the multivariate test statistics have very low values. Even the univariate F-tests are not significant. This implies that those households engaged in three market access options do not experience a major difference in nonfarm income from local sources (business and pensions), commuting (salaries), and migrating (wages). That could be due to the fact that farmers with access to the three market options are able to generate enough income (through sales), and ensure food security (through exchange and adding value themselves).

The multivariate test reflects that only one category of the three two-way interactions in market access is significant. The two-way interactions MKTSELL and MKTSELF had a multivariate test statistics significant at five percent. That is, when cash market is considered with value adding at household level, nonfarm income sources tend to show a major variation among groups. For that matter, the univariate F-test is significant at $5 \%$ level 
for local and migration income source. That is, income from local sources and migration differed significantly between households who used cash market and added value themselves and those who did not. However, income from commuting does not show any variation.

The multivariate test statistics for interactions between MKTEXC and MKTSELF and MKTSELL and MKTEXC were not significant. However, the univariate test reflected that nonfarm local income differ as to whether the household is engaged in exchanging for finished product and adding value self or not. This is significant at 10 percent. That is households in this category would use returns from farming for food security, and use income from nonfarm local sources to acquire other basic needs. Basically, this could be the results of absence of cash markets (MKTSELL $=0$ ). On the other hand, the univariate test for income from migration is significant at 10 percent for interaction of MKTSELL and MKTEXC. Households with access to these options are more likely to be earning supplementary income from migrants.

The main effects do not significantly explain the variation in the nonfarm income sources (Pillais, Hottelings and Wilks lamda statistics not significant). Only the univariate F-test for income from nonfarm local sources was significant. There is a 90 percent confidence that income from local sources differentiate those who sell for cash and those who don't (MKTSELL).

The MANOVA procedure further provided results for estimates of coefficients and post hoc estimation of means for different combinations of market access factors as well as combined adjusted means by each market access options. Those results are not presented in this paper, but are used for discussion of the results.

\section{CONCLUSIONS AND RECOMMENDATIONS}

Small-scale farming has dual objectives in farming; to ensure sufficient income and ascertain food security, normally achieved through access to agricultural markets. When access to cash market is constraint, households will typically engage in local nonfarm activities such as business operations (retailing, hawking, agribusiness) and service provision (building, welding, taxi operation), while senior citizens depend on pensions. However, when cash markets are available (usually locally), they are erratic and unreliable forcing households to exchange some produce for finished product or add value themselves. As such, some households tend to take wage employment in order to supplement and safeguard farming risk. However, households cannot respond to farming risks by generating income from commuting which 
is dominated by public service characterised by very specific entry requirements.

Participation in nonfarm income activities is a response of inadequacy of the farming activities to generate enough income and ensure food security for the household. These may reflect short-term response (through wage earning), medium term response (business, and services), and long term response (through salaries and pensions). These discernible linkages provide certain benefits, and they should be managed and promoted. At local level, market infrastructure for nonfarm local activities should be enhanced. Similarly, information and communication systens should be strengthened to strengthen interaction between migrants or wage eamers with household members operating the farms. For commuters to benefit more from farming activities, reliable transport and communication networks should be introduced. Management of these linkages is crucial since the dependency on both farm and nonfarm income is the mainstay of rural economies.

\section{REFERENCE}

ABDULAI, A. \& DELGADO, C.L. (1999). Determinants of non-farm earnings of farm-based husbands and wives in Northern Ghana. American Jourual of Agricultural Economics, 81.

APU - AGRICULTURAL POLICY UNIT. (1997). Food security policy for South Africa: A discussion document. For the Department of Agriculture and Land Affairs.

BABER, R. (1996). Current livelihoods in semi-arid rural areas of South Africa. In Lipton, M., Ellis, F. and Merle Lipton. Land, Labour and Liveliloods in Rural South Africa. Indicator: Durban.

BOSHOFF, A.B. \& SCHOLTZ, C.P.T. (1995). Measuring attitudes as a way of differentiating entrepreneurs. South African Journal of Econonics and Manngement Sciences, 16.

DELGADO, C.L. (1997). The role of smallholder income generation from agriculture in sub-Saharan Africa. In Haddad, L (ed). Achieving Food Security in Southern Africa: New challenges, new opportunities. IFPRI.

DELGADO, C., HAZELL, P., HOPKINS, J., \& KELLY, V. (1994). Promoting intersectoral growth linkages in rural Africa through agricultural technology and policy refórm. American Journal of Agricultural Economics, 76. 
DELGADO, C.L., HOPKINS, J., \& KELLY, V.A. (1998). Agricultuml growth linknges in sub-Sulurnn Africa. Research Report 107. IFPRI.

HAIR, J.F.JR, ANDERSON, R.E., TATHAM, R.L., \& BLACK, W.C. (1995). Multivariate datn analysis: With readings. 4 th ed. Prentice Hall: New Jersey.

ISLAM, N. (1997). The non-farm sector and rural development: Review of issues and evidence. IFPRI: DC.

JOHNSON, R.A., \& WICHERN, D.A. (1992). Applied multivariate statistical analysis. 3rd ed. Prentice Hall: New Jersey.

LIEDHOLM, C.; McPHERSON, M.; \& CHUTA, E. (1994). Small enterprise employment growth in rural Africa. American journal of Agricultural Economics, 76.

MALA - MINISTRY FOR AGRICULTURE AND LAND AFFAIRS. (1998). Agricultural policy in South Africa: A discussion document. NDA: Pretoria.

MAMABOLO, H.M. (1998). Multivariate analysis of variance (MANOVA) in agricultural economics. In Makhura M.T. (comp). Applications of Multivariate Statistical Analysis in Agricultural Economics. University of Pretoria. Unpublished.

MATHOBO, T.L. (1999). Application of multivariate analysis of variance (MANOVA) in agricultural economics. In Makhura M.T. (ed). Application of Multivariate Data Analysis in Agricultural Economics. University of Pretoria. Unpublished.

MAY, J. (1996). Assets, income and livelihoods in rural Kwazulu-Natal. In Lipton, M., Ellis, F. and Merle Lipton. Land, Labour and Livelihoods in Rural South Africa. Indicator: Durban.

MAY, J. (1997). Experience and perceptions of poverty in South A frica. A report for the Office of the Executive Deputy President and the Inter-Ministerial Committee for Poverty and Inequality. Praxis: Durban.

MUSSER, W.N. et al., (1986). Beliefs of farmers and adoption of intergrated pest management. Agricultural Economics Research. 38(1).

NAMC - NATIONAL AGRICULTURAL MARKETING COUNCIL. (1999). Report on the investigation into marketing access: Report on Phase 1. Pretoria. 
NGQANGWENI, S., KIRSTEN, J.F. \& DELGADO, C. (1999). Exploring grouth linknges ill a South Afrian smallholder farming area. Paper presented at the 37 th Annual Conference of the AEASA. Club Mykonos, Langebaan. 28-30 September 1999

OLFERT, R.M. (1992). Non-farm employment as a response to underemployment in agriculture. Canodian Journal of Agricultural Economics, 40:443-58

REARDON, T., CRAWFORD, E., \& KELLY, V. (1994). Links between nonfarm income and farm investment in African households: Adding the capital market Perspective. American Journal of Agricultural Economics, 76.

REARDON, T.; DELGADO, C.; \& MALTON, P. (1992). Determinants and effects of income diversification amongst farm households in Burkina Faso. Journal of Development Studies,

VAN DIJK, M.P. (1986). Non-agricultural production and rural development. In Rural Development for Poverty alleviation: Jubilee Symposium on the Effectiveness of Co-operation in Rural Development. Royal Tropical Institute/Rural Development. Amsterdam

VAN ROOYEN, C.J. (1997). Challenges and roles for agriculture in the Southern African region. Agrekon, 36(2).

WORLD BANK. (1995). Uganda - the challenge of growth and poverty reduction.

ZAIBET, L.T., \& DUNN, E. (1998) Land tenure, farm size, and rural market participation in developing countries: The case of Turisia Olive Sector. Economic Development and Cultural Change. 